\title{
Deteksi Dini dan Penguatan Literasi Siswa Sekolah Dasar
}

\author{
Hafidz Triantoro Aji Pratomo ${ }^{*}$, Windiarti Dwi Purnaningrum² \\ ${ }^{1,2}$ Jurusan Terapi Wicara, Poltekkes Kemenkes Surakarta \\ *Email: hafidztriantoro@poltekkes-solo.ac.id
}

\begin{abstract}
Background: language skills is essential processing that require in the learning processing. The students use language ability to listening, speaking, reading, and writing. Difficulty in the language skills may affects the academic achievement. The teacher needs to know how to do early detection learning difficulty. Awareness of language disorders and their correlation is important. The aims of this activity to increase teacher knowledge about language and learning difficulty. Also how to give basic activity to improve language and learning process. Methods: Mini seminar and mini workshop was used. Results: The teacher have a good knowledge about language and learning difficulty. Conclusion: This activity is effective to increase teacher awareness about language and learning process.
\end{abstract}

Keywords: language, learning, early detection, literacy

\section{PENDAHULUAN}

Kemampuan bahasa verbal dan bahasa tulis merupakan dua komponen yang terintegrasi dalam proses komunikasi akademik. Kemampuan bahasa menjadi indikator terbaik dalam kemampuan literasi dan kemampuan akademik siswa (Berninger et al., 2017; Beron \& Farkas, 2004; Roth et al., 2002; Tervo, 2007; Utchell et al., 2016). Kemampuan literasi siswa merupakan modal penting yang harus dikuasai anak untuk memiliki keberhasilan dalam prestasi akademik baik dalam proses membaca, menulis, dan matematika. Siswa dengan kemampuan bahasa dan literasi di bawah memiliki potensi yang tinggi dalam kegagalan akademis.

Kegagalan dalam prestasi akademik biasa dikaitkan dengan ketidakmampuan dalam intelegensi. Selain dipengaruhi intelegensi atau kemampuan kognitif secara umum, kegagalan akademik harus dikaitkan dengan kemampuan bahasa. Komponen bahasa mempengaruhi secara langsung dalam proses membaca dan menulis. Aspek fonologi, morfologi, sintaksis, semantik dan pragmatic secara komprehensif memberikan kontribusi linier terhadap kemampuan belajar. Kesulitan belajar yang ditandai dengan kesulitan dalam membaca, menulis, dan berhitung merupakan tanda dan gejala adanya gangguan belajar spesifik. Prevalensi gangguan belajar diperkirakan memiliki prosentase $9.4 \%$ dari keseluruhan siswa (Altarac \& Saroha, 2007). Secara spesifik ditemukan sekitar $5.7 \%$ siswa mengalami gangguan belajar spesifik (Morsanyi et al., 2018) serta ditemukan lebih dari 17\% siswa prasekolah terindikasi mengalami kesulitan belajar spesifik (McLeod \& McKinnon, 2007). Tidak ditemukan adanya data dan informasi tentang deteksi dini literasi. Bahkan kemampuan membaca dan menulis menjadi persyaratan masuk sekolah dasar di mana kemampuan tersebut baru akan diajarkan pada saat kelas 1 .

Upaya untuk meningkatkan pemahaman masyarakat tentang hubungan bahasa dan proses belajar merupakan sesuatu yang penting. Pemahaman gangguan belajar oleh guru dan orang tua dapat membantu dalam pemenuhan kebutuhan siswa. Identifikasi dini memperkecil risiko keterlambatan penanganan. Penanganan yang 
tepat mampu mempersempit kesulitan siswa sehingga proses belajar dapat dilakukan dengan optimal. Belum banyak guru dan orang tua yang memahami tentang deteksi dini gangguan bahasa dan literasi pada usia sekolah (Hunt et al., 2020; Shukla et al., 2015; Wilson et al., 2013). Dibutuhkan upaya nyata untuk memperkuat pemahaman bahasa dan literasi pada usia sekolah.

Kegiatan pengabdian kepada masyarakat menjadi jawaban untuk meningkatkan pemahaman masyarakat dalam melakukan deteksi dini permasalahan dan penguatan kemampuan literasi siswa. Sebagai salah satu penyelenggara sekolah dasar, SD Muhammadiyah memiliki keunggulan pada bidang akademik dan olahraga. Sekolah ini memiliki tenaga pengajar yang berkompeten pada bidangnya. Adanya rasio yang cukup antara guru dan siswa memberikan peluang yang tinggi dalam proses fasilitasi belajar anak. Kegiatan untuk memperkuat pemahaman dalam identifikasi dini dan penguatan literasi usia sekolah penting untuk dilakukan pada SD Muhammadiyah Bekonang.

\section{TINJAUAN PUSTAKA}

Komunikasi menggunakan sistem lambang yang disebut dengan bahasa. Kemampuan bahasa tersusun atas komponen bentuk bahasa, isi bahasa, dan penggunaan bahasa (Paul \& Norbury, 2012). Isi bahasa tersusun atas komponen fonologi, morfologi, dan sintaksis. Isi bahasa diatur oleh semantik pada level kata, kalimat, dan discourse. Kemampuan yang sudah dikuasai kemudian digunakan secara fungsional. Kemampuan menggunakan bahasa diatur oleh pragmatik. Bahasa terbagi menjadi dua proses yakni pemahaman ketika mendengar dan membaca, dan produksi ketika mengucapkan dan menulis. Literasi adalah kemampuan ekstensi bahasa yang terdiri dari kemampuan mendengar, mengucapkan, membaca, menulis dan berpikir. Komponen literasi yang utama adalah membaca, menulis, dan mengeja (Shipley \& McAfee, 2021). Kemampuan membaca dipengaruhi oleh tiga hal yakni kelancaran membaca, ketepatan decoding, dan pemahaman membaca. Sedangkan kemampuan menulis dipengaruhi oleh kemampuan mengeja, pungtuasi dan diksi, dan kejelasan dan pengorganisasian tulisan (Pennington, 2009).

Korelasi antara bahasa dan literasi bersifat eksisting. Artinya korelasi keduanya sifatnya baku dan saling berinteraksi (Connor, 2008). Kemampuan pemahaman membaca dipengaruhi oleh kemampuan memproses berbagai kemampuan bahasa secara bersamaan. Pemahaman membaca memerlukan kesadaran tentang aspek morfologi, sintaksis, dan semantik. Kesadaran fonologi memberikan kontribusi kepada siswa untuk memahami suatu bacaan (Shanahan, 2005). Kemampuan memahami sudut pandang dipengaruhi oleh kemampuan seorang siswa dalam memahami aspek pragmatik. Penelitian menunjukkan bahwa kosakata merupakan esensi penting dalam pencapaian akademik siswa (Davison et al., 2011; Weiland et al., 2013). Adanya limitasi kosakata dapat dijadikan prediksi tentang kesulitan belajar yang anak akan alami. Anak dengan riwayat gangguan bahasa dan bicara memiliki risiko yang tinggi untuk mengalami gangguan belajar pada usia sekolah.

Gangguan belajar merupakan bentuk dari neurodevelopmental disorder. Gangguan belajar spesifik merupakan gangguan yang ditandai adanya tiga kesulitan 
besar, yakni kesulitan dalam membaca, kesulitan dalam menulis, dan kesulitan dalam tugas matematis (American Psychiatric Association, 2013). Gangguan belajar yang bersifat ekstensi dari gangguan bahasa disebut dengan Language Learning Disability. Gangguan ini paling buruk berdampak pada pemahaman membaca. Berbeda dengan Disleksia, Disleksia lebih mengarah pada keterlambatan pemrosesan fonologi (Schuele \& Boudreau, 2008). Kesulitan ini diakibatkan adanya kesulitan dalam proses dekoding dan enkoding antara simbol grafem ke fonem atau sebaliknya.

Besarnya dampak gangguan belajar pada kualitas hidup siswa, diperlukan upaya deteksi dini dan penguatan literasi. Deteksi dini berperan besar dalam pemenuhan kebutuhan siswa. Dengan deteksi dini yang baik, anak akan segera mendapatkan pelayanan profesional. Kebutuhan tentang deteksi dini siswa dengan gangguan belajar spesifik, misalnya Disleksia, merupakan keharusan yang harus dikuasai (Kafia, 2014). Selain memerlukan pelayanan profesional, siswa juga memerlukan upaya penguatan yang dilakukan oleh guru dan atau orang tua. Beberapa aktivitas yang direkomendasikan dilakukan untuk penguatan literasi anak adalah meningkatkan kesadaran fonemik dan bercerita. Kesadaran fonemik dapat meningkatkan kemampuan proses dekoding dan enkoding siswa (Schuele \& Boudreau, 2008). Bercerita dapat membantu mengembangkan penguasaan kosakata siswa sehingga dapat meningkatkan kemampuan pemahaman membaca (Hogan et al., 2011).

\section{METODE}

Kegiatan pemberdayaan dilakukan dengan pendekatan seminar mini dan pelatihan mini. Seminar mini disajikan untuk memberikan konsep teoretis sehingga guru dan orang tua yang hadir memiliki pandangan korelasi antara komponen. Pelatihan mini bertujuan untuk memberikan guru dan orang tua bekal dalam proses penguatan literasi. Kegiatan diselingi dengan diskusi sehingga partisipan yang hadir dapat berinteraksi secara langsung dalam kegiatan pemberdayaan.

Tahapan dalam pelaksanaan terdiri dari proses penjajagan, permohonan perijinan, koordinasi pematangan, kegiatan pemberdayaan, dan evaluasi. Penjajagan lahan dilakukan untuk menilai kelayakan kebutuhan masyarakat tentang tema yang akan disajikan. Permohonan perijinan adalah persyaratan legal yang harus dipenuhi sebelum kegiatan berlangsung. Korodinasi pematangan dilakukan dengan mengundang perwakilan sekolah dasar SD Muhammadiyah Bekonang untuk bisa memberikan masukan tentang langkah-langkah yang perlu diambil dalam kegiatan. Kegiatan pemberdayaan dilakukan dengan kegiatan seminar mini dan pelatihan mini. Evaluasi dilakukan bersama pihak sekolah untuk menilai capaian target pemberdayaan.

Pemberdayaan dilakukan di SD Muhammadiyah Bekonang yang berlokasi di Kecamatan Mojolaban Kabupaten Sukoharjo. Kegiatan berlangsung pada hari Rabu pada tanggal 19 Agustus 2020 bertempat di Aula Gedung baru SD Muhammadiyah Bekonang. Kegiatan dihadiri oleh 56 peserta dengan kuesioner yang kembali berjumlah 28 orang. Undangan adalah guru, tenaga kependidikan, dan orang tua 
siswa. Seminar mini membahas tentang konsep gangguan bahasa dan gangguan belajar. Pelatihan yang disajikan adalah aktivitas dalam penguatan literasi.

\section{HASIL}

Kegiatan berlangsung dengan lancar. Undangan disebar dengan jumlah 60 peserta. Kegiatan dihadiri oleh 56 peserta namun kuesioner yang kembali terkumpul adalah sebanyak 28 responden. Adapun rincian hasil kegiatan dan data dijelaskan sebagai berikut. Data demografi yang diungkap adalah jenis kelamin responden dan usia responden. Data demografi dituangkan dalam tabel di bawah ini.

Tabel 1. Data Demografi.

\begin{tabular}{lc}
\hline Variabel & Frekuensi dan Mean \\
\hline Jenis Kelamin & 7 \\
Laki-laki & 21 \\
Perempuan & $30.86 \pm 8.09$ \\
Usia & 25 \\
Pengalaman & 3 \\
Pernah melihat anak dengan kesulitan komunikasi & \\
Belum pernah melihat anak dengan kesulitan komunikasi & \multicolumn{2}{c}{ Pengetahuan responden setelah mengikuti kegiatan diukur dengan menjawab } \\
pertanyaan yang diajukan. Setiap skor benar memiliki nilai 10. Total item adalah 10 \\
sehingga skor maksimal adalah 100. Mean nilai responden adalah 80.36 \pm 9.22. nilai \\
tersebut menunjukkan bahwa nilai rerata responden adalah baik. Persepsi klien \\
diukur dengan memberikan penilaian yang terdiri dari empat tingkatan. Tingkatan \\
tersebut antara lain tidak perlu, cukup perlu, perlu, dan sangat perlu. Total yang \\
ditanyakan adalah 4 item dengan skor total 16. Nilai rerata persepsi adalah 14.25 \pm \\
1.6. Rincian hasil persepsi dijelaskan sebagai berikut.
\end{tabular}

Tabel 2. Jabaran Persepsi Responden

\begin{tabular}{lc}
\hline Pernyataan dan Persepsi & n \\
\hline Terapis Wicara diperlukan dalam Pelayanan Publik & 11 \\
Perlu & 17 \\
Sangat perlu & \\
Upaya Deteksi Dini dapat dilakukan Ketika Anak Masuk SD & 1 \\
Tidak perlu & 5 \\
Cukup perlu & 8 \\
Perlu & 14 \\
Sangat perlu & \\
Penguatan Kemampuan Komunikasi perlu dikolaborasi & 12 \\
Perlu & 16 \\
Sangat perlu & \\
Kemampuan Belajar dapat Meningkat dengan Penguatan Bahasa & 5 \\
Perlu & 23 \\
Sangat perlu &
\end{tabular}


Analisis korelasi diperlukan untuk melihat hubungan lebih lanjut dari setiap komponen yang mempengaruhi pengetahuan dan persepsi responden. Variabel yang dihubungkan adalah usia, jenis kelamin, pengalaman dengan anak dengan kesulitan komunikasi, pengetahuan dan persepsi tentang terapi wicara.

Tabel 3. Usia, Pengetahuan dan Persepsi

\begin{tabular}{lcccc}
\hline & Mean \pm SD & $\mathbf{1}$ & $\mathbf{2}$ & $\mathbf{3}$ \\
\hline Usia & $30.86 \pm 8.09$ & $\mathbf{1 . 0 0}$ & & \\
Pengetahuan & & - & & \\
Persepsi & $80.36 \pm 9.22$ & 0.080 & $\mathbf{1 . 0 0}$ & \\
& & 0.685 & - & \\
& $14.25 \pm 1.60$ & 0.131 & 0.057 & $\mathbf{1 . 0 0}$ \\
\hline
\end{tabular}

Tabel tersebut memberikan informasi bahwa usia, pengetahuan, dan persepsi tidak memiliki hubungan.

Hubungan antara jenis kelamin, pengalaman, pengetahuan, dan persepsi dijelaskan dalam tabel di bawah ini. Hubungan antara jenis kelamin, pengetahuan, dan persepsi dilakukan dengan melakukan analisis uji Mann Whitney. Hasil analisis sebagai berikut:

Tabel 4. Hubungan Jenis Kelamin, Pengetahuan, dan Persepsi

\begin{tabular}{lcc}
\hline & Pengetahuan & Persepsi \\
\hline Jenis kelamin & $\mathrm{p}=0.029$ & $\mathrm{p}=0.029$ \\
\hline
\end{tabular}

Tabel tersebut menunjukkan bahwa jenis kelamin responden memiliki hubungan dengan pengetahuan dan persepsi.

Hubungan antara jenis kelamin, pengetahuan, dan persepsi dilakukan dengan melakukan analisis uji Mann Whitney. Hasil analisis sebagai berikut:

Tabel 5. Hubungan Pengalaman, Pengetahuan, dan Persepsi

\begin{tabular}{lcc}
\hline & Pengetahuan & Persepsi \\
\hline Pengalaman & $\mathrm{p}=0.455$ & $\mathrm{p}=0.029$ \\
\hline
\end{tabular}

Tabel tersebut menunjukkan bahwa pengalaman responden tidak memiliki hubungan dengan pengetahuan namun memiliki hubungan dengan persepsi.

\section{PEMBAHASAN}

Komponen bahasa oral merupakan komponen esensial yang memiliki korelasi langsung dengan capaian akademik. Anak atau siswa yang memiliki kemampuan bahasa oral yang mumpuni memiliki potensi yang lebih besar untuk meraih kesuksesan dalam capaian akademik melalui aktivitas membaca dan menulis (Berninger et al., 2017; Beron \& Farkas, 2004; Roth et al., 2002). Penguasaan kemampuan awal literasi memiliki kontribusi yang besar dalam tahapan perkembangan literasi. Diperlukan penguasaan tentang perkembangan awal literasi dan literasi. 
Orang tua dan guru hendaknya mengetahui dan memahami tahapan perkembangan bahasa dan literasi anak. Kemampuan bahasa dan literasi banyak dipengaruhi oleh lingkungan rumah dan sekolah (Davison et al., 2011; Pratomo et al., 2016; Weiland et al., 2013). Melalui dua tempat utama ini, anak belajar mengembangkan kemampuan bahasa dan literasi secara berkesinambungan. Pemahaman yang baik memiliki peranan dalam identifikasi dini maupun dalam tindakan yang mungkin diperlukan.

Diskusi dua arah antara pengabdi dan peserta kegiatan merupakan salah satu proses yang terjadi dalam kegiatan ini. Peserta memberikan pertanyaan seputar bagaimana cara memberikan aktivitas-aktivitas dasar dalam penguatan bahasa dan literasi. Penting bagi orang tua untuk mengetahui fasilitasi kemampuan literasi (Wilson et al., 2013). Ketika orang tua mengetahui cara bagaimana memberikan aktivitas, resiko anak untuk mengalami kondisi yang lebih buruk akan terhindar. Aktivitas yang dilakukan secara rutin secara positif akan meningkatkan kualitas anak dalam belajar.

Kegiatan pengabdian kepada masyarakat yang telah dilakukan memberikan manfaat dalam meningkatkan pemahaman responden. Hal ini dibuktikan dengan nilai rata-rata responden yang berada pada angka di atas 80 yang sebelum kegiatan memiliki nilai rerata kurang dari 70. Nilai ini mempresentasikan bahwa pengetahuan responden yakni orang tua dan guru memiliki pengetahuan yang baik setelah dilakukan kegiatan penyuluhan. Dampak lain yang bisa dirasakan adalah adanya persepsi yang baik terhadap profesi terapis wicara. Orang tua dan guru memberikan persepsi bahwa profesi terapis wicara dapat berperan lebih dalam peningkatan kemampuan bahasa dan literasi anak.

\section{KESIMPULAN DAN SARAN}

\subsection{Kesimpulan}

Kegiatan dilaksanakan dengan melibatkan guru dan orang tua siswa SD Muhammdiyah Bekonang. Kegiatan dilaksanakan dengan pendekatan seminar mini dan diskusi antara pengabdi, guru, dan orang tua. Topik bahasa yang disajikan adalah korelasi antara bahasa verbal dan tulis terhadap kemampuan akademik siswa SD. Hasil kegiatan menunjukkan bahwa persepsi dan pengetahuan guru memiliki nilai di atas rata-rata yang diharapkan $(70 \& 12)$.

\subsection{Saran}

Diperlukan perencanaan yang matang dengan pendekatan hybrid ketika merencanakan kegiatan pengabdian masyarakat tahun depan. Perlu adanya perluasan spektrum responden sehingga kegiatan memiliki daya ungkit yang lebih luas. Misalnya dengan menambah jumlah responden yang dalam hal ini adalah jumlah sekolah, guru, dan orang tua.

\section{UCAPAN TERIMA KASIH}

Ucapan terima kasih diucapkan kepada Politeknik Kesehatan Kemenkes Surakarta yang telah mengalokasikan anggaran kegiatan pemberdayaan ini. Terima 
kasih diucapkan kepada seluruh pihak dari SD Muhammadiyah Bekonang yang telah berpartisipasi dalam kegiatan pemberdayaan ini.

\section{DAFTAR RUJUKAN}

Altarac, M., \& Saroha, E. (2007). Lifetime prevalence of learning disability among US children. Pediatrics, 119(SUPPL. 1), S77-S83. https://doi.org/10.1542/peds.2006-2089L

American Psychiatric Association. (2013). Diagnostic and statistical manual of mental disorders : DSM-5. In Pediatria Integral (5th Editio, Vol. 17, Issue 7). American Psychiatric Association.

Berninger, V., Abbott, R., Cook, C. R., \& Nagy, W. (2017). Relationships of Attention and Executive Functions to Oral Language, Reading, and Writing Skills and Systems in Middle Childhood and Early Adolescence. Journal of Learning Disabilities, 50(4), 434-449. https://doi.org/10.1177/0022219415617167

Beron, K. J., \& Farkas, G. (2004). Oral language and reading success: A structural equation modeling approach. Structural Equation Modeling, 11(1), 110-131. https://doi.org/10.1207/S15328007SEM1101_8

Connor, C. M. (2008). Language and Literacy Connections for Children Who are African American. Perspectives on Communication Disorders and Sciences in Culturally and Linguistically Diverse (CLD) Populations, 15(2), 43-53. https://doi.org/10.1044/cds15.2.43

Davison, M. D., Hammer, C., \& Lawrence, F. R. (2011). Associations between preschool language and first grade reading outcomes in bilingual children. Journal of Communication Disorders, 44(4), 444-458. https://doi.org/10.1016/j.jcomdis.2011.02.003

Hogan, T. P., Bridges, M. S., Justice, L. M., \& Cain, K. (2011). Increasing Higher Level Language Skills to Improve Reading Comprehension. Focus on Exceptional Children, 44(3). https://doi.org/10.17161/fec.v44i3.6688

Hunt, J., Zwicker, J. G., Godecke, E., \& Raynor, A. (2020). Awareness and knowledge of developmental coordination disorder: A survey of caregivers, teachers, allied health professionals and medical professionals in Australia. Child: Care, Health and Development, April, 1-10. https://doi.org/10.1111/cch.12824

Kafia, E. (2014). Teachers and Parents Awareness - a Key Factor To Success of Inclusive Education. European Scientific Journal October, 10(28), 327-335. 
McLeod, S., \& McKinnon, D. H. (2007). Prevalence of communication disorders compared with other learning needs in 14500 primary and secondary school students. International Journal of Language and Communication Disorders, 42(SUPPL. 1), 37-59. https://doi.org/10.1080/13682820601173262

Morsanyi, K., van Bers, B. M. C. W., McCormack, T., \& McGourty, J. (2018). The prevalence of specific learning disorder in mathematics and comorbidity with other developmental disorders in primary school-age children. British Journal of Psychology, 109(4), 917-940. https://doi.org/10.1111/bjop.12322

Paul, R., \& Norbury, C. F. (2012). Language Disorders from Infancy Through Adolescence: Listening, Speaking, Reading, Writing, and Communicating (Fourth Edi). Mosby Elsevier Inc.

Pennington, B. F. (2009). Diagnosing Learning Disorders: A Neuropsychological Framework (Second Edi). The Guilford Press.

Pratomo, H. T. A., Adriani, R. B., \& Akhyar, M. (2016). Association Between Parental Education, Occupation, Income, Language Activity, and Language Proficiency in Children. Indonesian Journal of Medicine, 01(03), 152-159. https://doi.org/10.26911/theijmed.2016.01.03.02

Roth, F. P., Speece, D. L., \& Cooper, D. H. (2002). A longitudinal analysis of the connection between oral language and early reading. Journal of Educational Research, 95(5), 259-272. https://doi.org/10.1080/00220670209596600

Schuele, C. M., \& Boudreau, D. (2008). Phonological awareness intervention: Beyond the basics. Language, Speech, and Hearing Services in Schools, 39(1), 3-20. https://doi.org/10.1044/0161-1461(2008/002)

Shanahan, T. (2005). The National Reading Panel Report: Practical Advice for Teachers. In Learning Point Associates. http://eric.ed.gov/ERICWebPortal/recordDetail?accno=ED489535

Shipley, K. G., \& McAfee, J. G. (2021). Assessment in speech-language pathology: a resource manual (Sixth edit). Plural Publishing, Inc.

Shukla, P., Agrawal, G., \& Shukla, M. P. (2015). Awareness of Learning Disabilities among Teachers of Primary Schools. OJMR International Journal Online Journal of Multidisciplinary Research, 1(11), 33-38.

Tervo, R. C. (2007). Language Proficiency, Development, and Behavioral Difficulties in Toddlers. Clinical Pediatrics, 46(6), 530-539. https://doi.org/10.1177/0009922806299154 
Utchell, L. A., Schmitt, A. J., McCallum, E., McGoey, K. E., \& Piselli, K. (2016). Ability of Early Literacy Measures to Predict Future State Assessment Performance. Journal of Psychoeducational Assessment, 34(6), 511-523. https://doi.org/10.1177/0734282915621221

Weiland, C., Ulvestad, K., Sachs, J., \& Yoshikawa, H. (2013). Associations between classroom quality and children's vocabulary and executive function skills in an urban public prekindergarten program. Early Childhood Research Quarterly, 28(2), 199-209. https://doi.org/10.1016/j.ecresq.2012.12.002

Wilson, B. N., Neil, K., Kamps, P. H., \& Babcock, S. (2013). Awareness and knowledge of developmental co-ordination disorder among physicians, teachers and parents. Child: Care, Health and Development, 39(2), 296-300. https://doi.org/10.1111/j.1365-2214.2012.01403.x 